Correlation between hardness and water absorption properties of Saudi kaolin and white clay geopolymer coating

Shamala Ramasamy, Mohd Mustafa Al Bakri Abdullah, Yue Huang, Kamarudin Hussin, Jin Wang, and Noor Fifinatasha Shahedan

Citation: AIP Conference Proceedings 1885, 020224 (2017); doi: 10.1063/1.5002418

View online: $\mathrm{http} / / / \mathrm{dx}$.doi.org/10.1063/1.5002418

View Table of Contents: http://aip.scitation.org/toc/apc/1885/1

Published by the American Institute of Physics

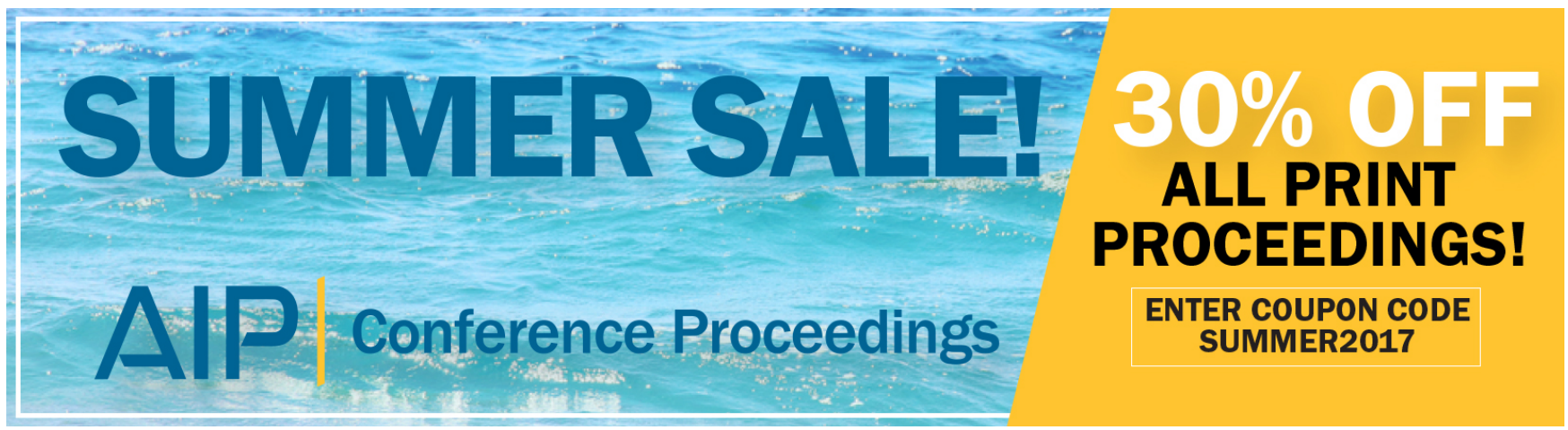




\title{
Correlation between Hardness and Water Absorption Properties of Saudi Kaolin and White Clay Geopolymer Coating
}

\author{
Shamala Ramasamy ${ }^{1,2,3, a)}$, Mohd Mustafa Al Bakri Abdullah ${ }^{1,2,3, c)}$, Yue Huang \\ 3,b) , Kamarudin Hussin ${ }^{1,2, \mathrm{~d})}$, Jin Wang ${ }^{1,3, \mathrm{e})}$ and Noor Fifinatasha Shahedan ${ }^{1,2, \mathrm{f})}$ \\ ${ }^{1}$ Center of Excellence Geopolymer and Green Technology, School of Materials Engineering, Universiti Malaysia \\ Perlis (UniMAP), 01007, P.O Box 77, D/A Pejabat Pos Besar, Kangar, Perlis, Malaysia \\ ${ }^{2}$ Faculty of Engineering Technology, Universiti Malaysia Perlis (UniMAP), P.O. Box 77, D/A Pejabat Pos Besar, \\ Kangar, Perlis 01000, Malaysia. \\ ${ }^{3}$ Faculty of Engineering and Technology, Liverpool John Moores University, \\ Cherie Booth Building, Byrom St, Liverpool, L3 3AF, United Kingdom. \\ Corresponding author: a)shamala_ramasamy@yahoo.com \\ ${ }^{b)}$ mustafa_albakri@unimap.edu.my \\ ${ }^{c}$ Y.Huang@ljmu.ac.uk \\ d)kamarudin@unimap.edu.my \\ e)J.Wang@ljmu.ac.uk \\ f)sfifinatasha@yahoo.com
}

\begin{abstract}
Geopolymer is an uprising technology that is being studied worldwide. Geopolymer raw materials are basically aluminosilicate source materials. However, this technology is yet to infiltrate into pipelines and coating industries which initiated our research idea. The idea of creating universal geopolymer based coating material is mainly to help oil and gas industry reduce its maintenance cost. Kaolin based geopolymer paste was coated on glass reinforced epoxy (GRE) substrates which are majorly used as pipeline material in the oil and gas industry at Saudi Arabia. Kaolin and white clay was chosen as raw material to study the possibilities of utilizing underused aluminosilicate raw materials for geopolymer coating. To obtain suitable formulation, $\mathrm{Na}^{2} \mathrm{SiO}^{3} / \mathrm{NaOH}$ ratio was varied from 0.40 untill 0.60 while other parameters such as solid/liquid ratio and $\mathrm{NaOH}$ molarity were kept constant at values as per previous works. Geopolymer coated GRE substrates were then subjected to water absorption, flexural strength and hardness test to validate our findings. Water absorption is a crucial test as for coating materials which justifies the pratical usability of the coating product. Upon testing, kaolin and white clay based geopolymer coating each shows promising properties at $\mathrm{Na}^{2} \mathrm{SiO}^{3} / \mathrm{NaOH}$ ratio of 0.45 and 0.50 each.
\end{abstract}

\section{INTRODUCTION}

Geopolymer is a group of three-dimensionally networked by synthetic alumina-silicate materials which is similar to natural zeolite minerals, and first developed by Joseph Davidovits in 1978 [1-3]. Aluminosilicate source materials dissolve with alkaline solution which alter into tridimensional tecto-aluminosilicate materials are known as Geopolymers. Commonly used geopolymer source materials such as granulated blast furnace slag (GBFS), kaolin, metakaolin and fly ash which contains mostly high content in silica (Si), alumina (Al), calcium (Ca) and ferum $(\mathrm{Fe})$. Geopolymer source material reacted as aluminosilicate source dissolved by alkaline solution in geopolymerization process to produce geopolymer coating. Various application of geopolymers are possible depending on the formulation and chemical composition as shown in Table 1. 
TABLE 1. Possible application of the geopolymers depending on the chemical composition based $\mathrm{Si} / \mathrm{Al}$ ratio [7].

\begin{tabular}{|c|l|}
\hline $\mathrm{Si} / \mathrm{Al}$ & Application \\
\hline 1 & Bricks, ceramics, fire protection \\
\hline 2 & Low $\mathrm{CO}_{2}$ cements, concrete, radioactive and toxic waste encapsulation \\
\hline 3 & Heat resistance composites, foundry equipments, fibre glass composites \\
\hline$<3$ & Sealants or coating for industry \\
\hline $20<\mathrm{Si} / \mathrm{Al}<35$ & Fire resistance and heat resistance fibre composites \\
\hline
\end{tabular}

Previous research work has used the merger of sodium hydroxide and sodium silicate as alkaline activator [4-6] and attempted to prepared coating paste by mixing fly ash with alkaline activator solution. It is different from ordinary Portland/pozzolanic cementious paste, geopolymer do not form calcium-silicate-hydrates (CSHs) for matrix formation and strength, but utilize the polycondensation of alumina and silica precursors towards achieve structural strength. Hence, geopolymer coating illustrated a new concept and excellent potential of cementitious coating in coating application.

Cementitious coatings are among the oldest product used for water resistance application and mostly cementitious materials include traditional Portland cement. Cementitious coatings are highly resistant to accelerated weathering, as well as being salt-resistant and also widely used on bridges and roads, to protect exposed concrete from salts, which can damage reinforcing steel by chloride attack. However, the used of Portland cement has generates carbon dioxide $\left(\mathrm{CO}_{2}\right)$ through calcinations of raw materials and fuel consumption [8]. The manufacturing of cement and the combustion of fossil fuels involved the process of de-carbonate of limestone in the furnace which brought to the production of 1 ton carbon dioxide $\left(\mathrm{CO}_{2}\right)$ in making of 1 ton of Portland cement $[8,11-13]$. Besides, the production of the Portland cement has increased the emission of greenhouse gas which is estimated around 1.35 billion tonnes per year and it is expected to increase up to 3500 million tonnes in the next 5 years [14-15]. Furthermore, cementitious coating is one of the most demanding service environments as protective coating in flooring application [16]. Though, most of cementitious materials are using Portland cement as main material which is harmful to the environment.

Therefore all types of engineering process technologies, analytical chemistry, physical chemistry, geology, mineralogy, modern inorganic chemistry, scientific and industrial, has developed the versatility of new green technology concept without any use of Portland cement which is geopolymer. Any country that change to the manufacture of geopolymeric cement would eliminate about $80 \%$ of the emission generated from the cement industries. Geopolymer features a $90 \%$ or greater reduction in carbon dioxide emission [9]. Geopolymer has great potential in refractory items, low energy ceramics tiles, building materials, new binder for fibre composite, and it is a new material for cementitious coating materials [17-18]. Previously, organic coatings such as chlorinated rubber coating, epoxy resin coating, acrylic coating and polyurethane coating have been practical on metallic and non-metallic substrate. Though, the factor of chemical and physical impact on environment, the aging under daylight condition has lead to the durability of the organic coatings becomes doubtful. Therefore by using inorganic polymers which also called as 'geopolymer', may be an alternative choice in coating application as protective coating materials. Our work studies on the mechanical properties of Saudi kaolin and white clay geopolymer coating. The geopolymer coating was coated on glass reinforced epoxy (GRE) substrates. This is to ensure the suitability of kaolin and white clay geopolymer coating on GRE which is commonly used as pipeline materials in Saudi Arabia. To best of our knowledge, no similar work have been intended or worked on before which makes it a novel idea. However the focus of this article will only be on water absorption, hardness and flexural strength.

\section{Raw Materials}

Kaolin and white clay, which are the main ingredients used in our research work was obtained from King Abdulaziz City for Science and Technology (KACST), Saudi Arabia. Kaolin and white clay were sieved using desired mesh size and stored in an air tight container at our laboratory. This step was to minimize exposure towards moisture and dust. The sodium chloride pellets were bought from Formosa Plastic Corporation, Taiwan while sodium silicate solution was purchased from South Pacific Chemicals Industries Sdn. Bhd. Malaysia. 


\section{Sample Preparation}

Kaolin and white clay are the solid component and alkaline activator is the liquid part of our geopolymer material. Alkaline activator solution is prepared by mixing the liquid $\mathrm{Na}_{2} \mathrm{SiO}_{3}$ and $\mathrm{NaOH}$ solution together 24 hours prior to use. This is to allow complete mixing of the solution. The ratio of $\mathrm{Na}_{2} \mathrm{SiO}_{3} / \mathrm{NaOH}$ was varied from $0.40,0.45,0.50,0.55$ and 0.60 while molarity of sodium chloride solution and solid /alkaline activator ratio were kept constant at $8 \mathrm{M}$ and 1.0. Solid and liquid content was mixed in a mechanical stirrer for 5 minutes at the speed of 20rpm until a well mixed geopolymer paste were obtained.This paste is then coated on the glass reinforced epoxy substrates. The coated samples were left at room temperature until it sets. There were the moved to the oven for curing process at $60^{\circ} \mathrm{C}$. After 4 hours, samples were removed from the oven to be tested for flexural strength test.

\section{Water absoprtion Test}

Water resistance is tested on cured geopolymer coating sample using static immersion test which include immersion of the sample in distilled water at $25^{\circ} \mathrm{C}$ for 24 hours and weight after drying at $40{ }^{\circ} \mathrm{C}$ for 1 hour. The result shows less than $2 \%$ which is relatively little change in the mass of the coated sample with time immersed in water representing excellent water stability. This water immersion testing is accordance to ASTM D 870.

$$
\text { Water Change, } \mathrm{W}_{\mathrm{C}} \quad=\frac{\mathrm{W}_{2}}{\mathrm{~W}_{1}} \frac{\mathrm{W}_{1}}{1} \times 100 \%
$$

Where,

$\mathrm{W}_{\mathrm{C}} \quad$ weight change

$\mathrm{W}_{1} \quad$ weight before water immersion

$\mathrm{W}_{2} \quad$ weight after water immersion and drying

\section{Hardness Test}

Vickers hardness is microhardness test method mostly used to measure the resistance indentation. Hardness is a test to measure of a material's resistance to localised plastic deformation that suitable to determine the hardness of coating paste in this research after cured at $75^{\circ} \mathrm{C}$ for 2 days. The test procedure has specifies a range of light loads using a diamond indenter to make an indentation which is converted and measured to a hardness value as follows ASTM E 384. Hardness test is useful for geopolymer coating resistance and as a cementitious type of material that do not have a very high; therefore this test is very suitable. Vickers hardness number, Hv is a number represent the hardness value related to the the area of an indent and applied force $(\mathrm{P})$ is given by a square-based pyramidal diamond indenter having included face angle of $136^{\circ}$ as shows in Figure 1.

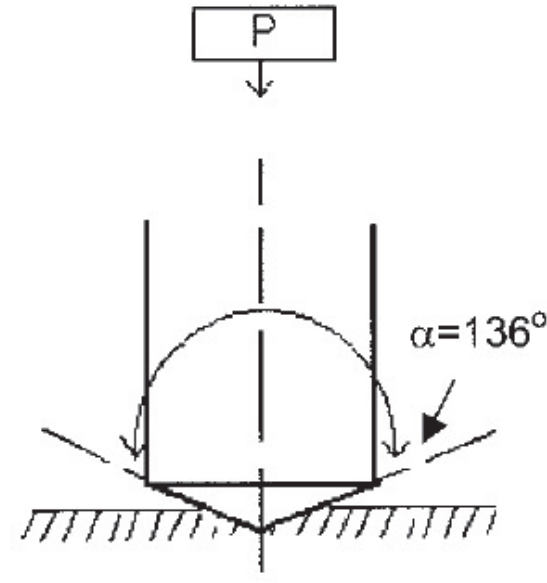

(a)

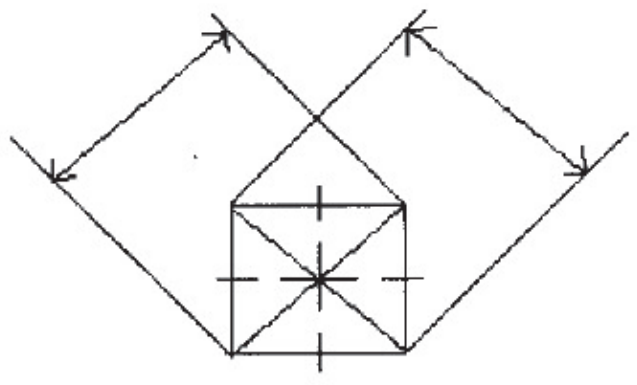

(b)

FIGURE 1. Vickers indentation (a) side view of diamond indenter (b) plan view of indent (ASTM E 384) 
The Vickers hardness (Hv) in MPa is calculated using the following formula,

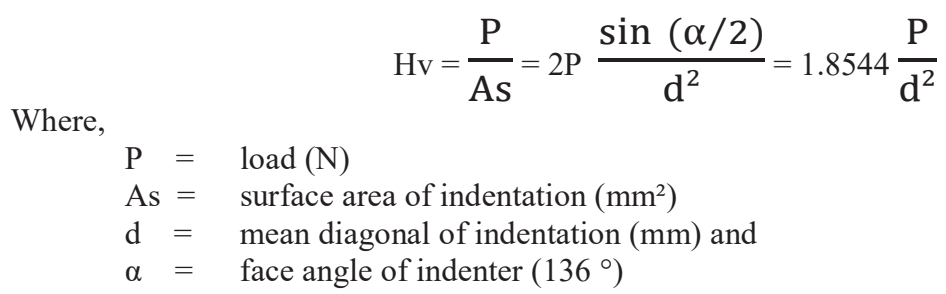

\section{RESULTS AND DISCUSSIONS.}

\section{Water Absorption Properties}

The water absorption test was conducted to investigate the water resistance properties of coated GRE sample with kaolin and white clay coatings. The testing is conducted after 3 days coating [18]. The water resistance test conducted for $24 \mathrm{~h}$ also showed very good results in case of all the coatings. Figure 2 have shown that the water absorption of geopolymer coating on GRE pipe sample is directly related to the mix design in geopolymer coating.

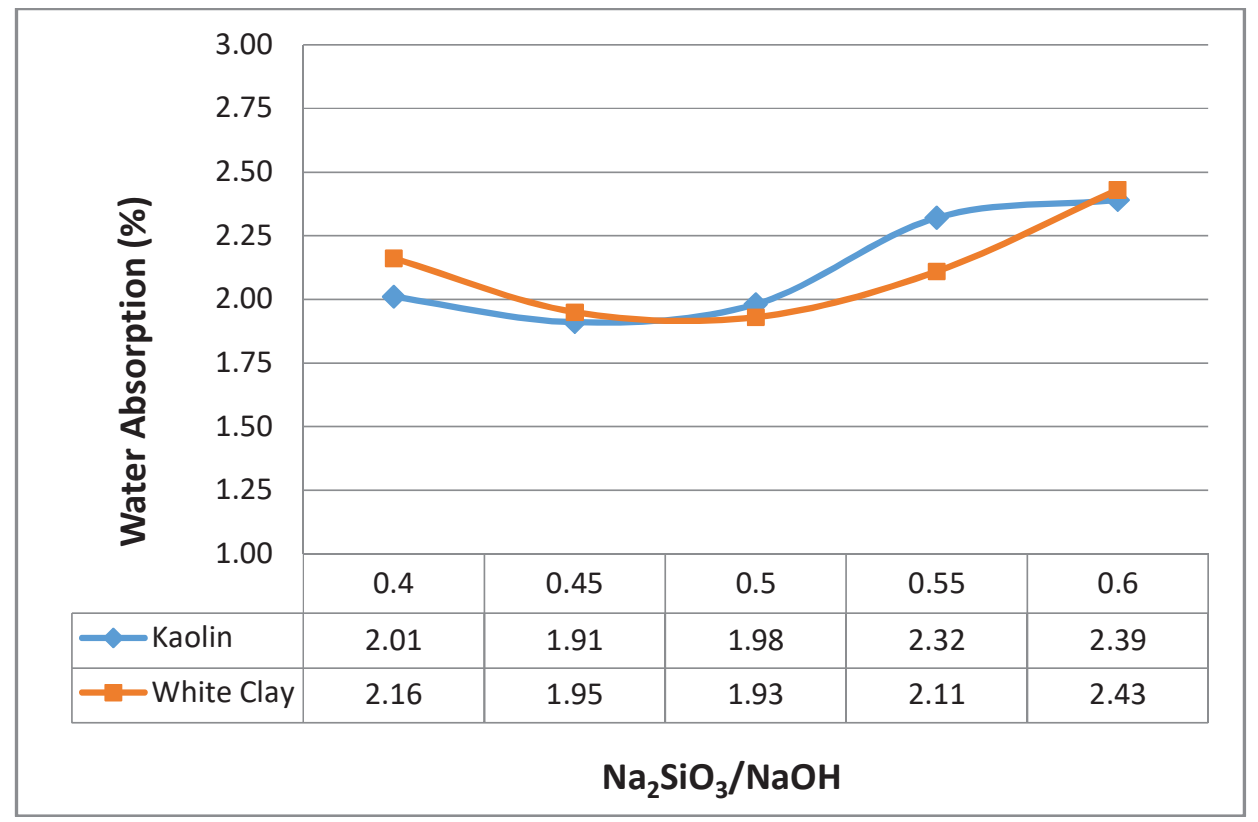

FIGURE 2. Percentage water absorption determined for different $\mathrm{Na}_{2} \mathrm{SiO}_{3} / \mathrm{NaOH}$

However, there was not much different between the results obtained for coated sample with different $\mathrm{Na}_{2} \mathrm{SiO}_{3} / \mathrm{NaOH}$ ratio. The kaolin geopolymer coating shows the good result at less percent of water absorption at ratio of solid/liquid 1.0 and $\mathrm{Na}_{2} \mathrm{SiO}_{3} / \mathrm{NaOH}$ ratio at 0.45 while for white clay at solid/liquid ratio 1.0 and $\mathrm{Na}_{2} \mathrm{SiO}_{3} / \mathrm{NaOH}$ ratio at 0.50 . This result is related to the best design of geopolymer coating and the coating layer condition which at this ratio the coating layer was in good condition without any crack and complete curing of the coating formulation. The surface condition of coating layer has influence the water absorption in geopolymer coating. Overall, the water absorption in each case was not significantly higher and all samples gave the result below $3 \%$ of water absorption.

\section{Hardness Properties}

Vickers hardness is conducted to measure the resistance to permanent deformation or damage layer of geopolymer coating supported by GRE pipe substrate. The applied load used for geopolymer is in range of $0.1-$ $1.5 \mathrm{~kg}$ appropriate to the hardness of cementitious materials in geopolymer coating [19,20]. In this research, the applied load was used $1.0 \mathrm{~kg}(9.807 \mathrm{~N})$ which provided a reasonable indent for geopolymer coating hardness determination. 
TABLE 2. Hardness values kaolin and white clay geopolymer coating at different $\mathrm{Na} 2 \mathrm{SiO} 3 / \mathrm{NaOH}$ ratio

\begin{tabular}{|c|c|c|c|c|c|}
\hline Sample & Solid/Liquid & $\mathrm{Na}_{2} \mathrm{SiO}_{3} / \mathrm{NaOH}$ & $\begin{array}{c}\text { Vickers } \\
\text { Hardness, } \\
\text { Hv }\end{array}$ & $\mathrm{Hv}(\mathrm{MPa})$ & $\mathrm{Hv}(\mathrm{GPa})$ \\
\hline \multirow{4}{*}{ Kaolin } & 1.00 & 0.40 & 22.34 & 219.1 & 0.22 \\
\cline { 2 - 6 } & 1.00 & 0.45 & 23.43 & 229.8 & 0.23 \\
\cline { 2 - 6 } & 1.00 & 0.50 & 22.93 & 224.9 & 0.22 \\
\cline { 2 - 6 } & 1.00 & 0.55 & 22.69 & 222.5 & 0.22 \\
\hline \multirow{4}{*}{$\begin{array}{c}\text { White } \\
\text { Clay }\end{array}$} & 1.00 & 0.60 & 22.17 & 217.4 & 0.22 \\
\cline { 2 - 6 } & 1.00 & 0.40 & 22.86 & 224.2 & 0.22 \\
\cline { 2 - 6 } & 1.00 & 0.45 & 22.84 & 224.0 & 0.22 \\
\cline { 2 - 6 } & 1.00 & 0.50 & 23.73 & 232.1 & 0.23 \\
\hline
\end{tabular}

According to the Vickers hardness testing for the variation ratio of $\mathrm{Na}_{2} \mathrm{SiO}_{3} / \mathrm{NaOH}$, it has been found that the hardness of the coated sample has not much different as recorded in Table 2.

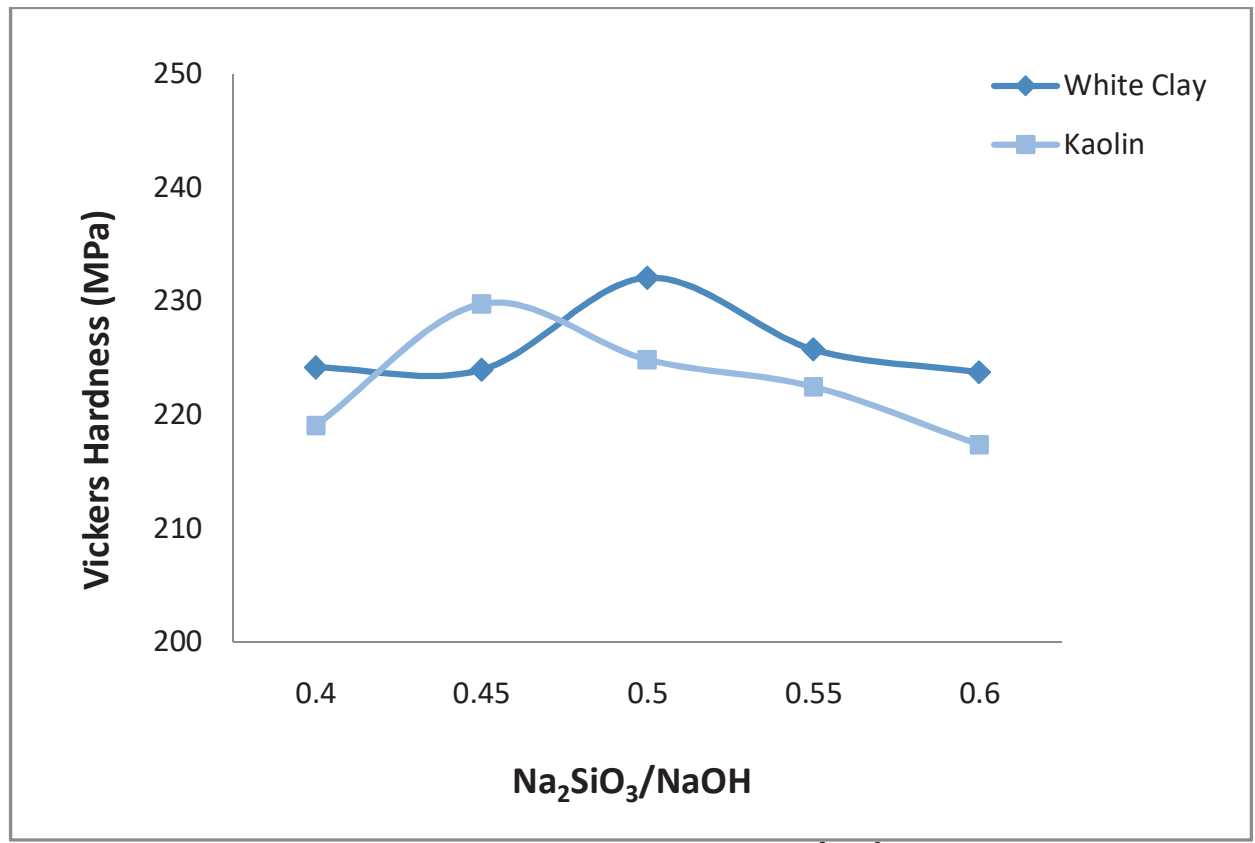

FIGURE 3. The effect of hardness strength on different $\mathrm{Na}^{2} \mathrm{SiO}^{3} / \mathrm{NaOH}$ ratio

In particular, hardness test such as Vickers hardness testing provide result of relationship of mechanical properties of with the effect chemical component of cementitious materials [21-23]. The hardness strength result is explained with the variation of $\mathrm{Na}_{2} \mathrm{SiO}_{3} / \mathrm{NaOH}$ ratio in Figure 3. It has been found from experimental data analysis of hardness strength that the maximum result of 229.8 and $232.1 \mathrm{MPa}$ reached $\mathrm{at}_{2} \mathrm{Na}_{2} \mathrm{SiO}_{3} / \mathrm{NaOH}$ ratio 0.45 and 0.50 for kaolin and white clay geopolymer coating respectively. 


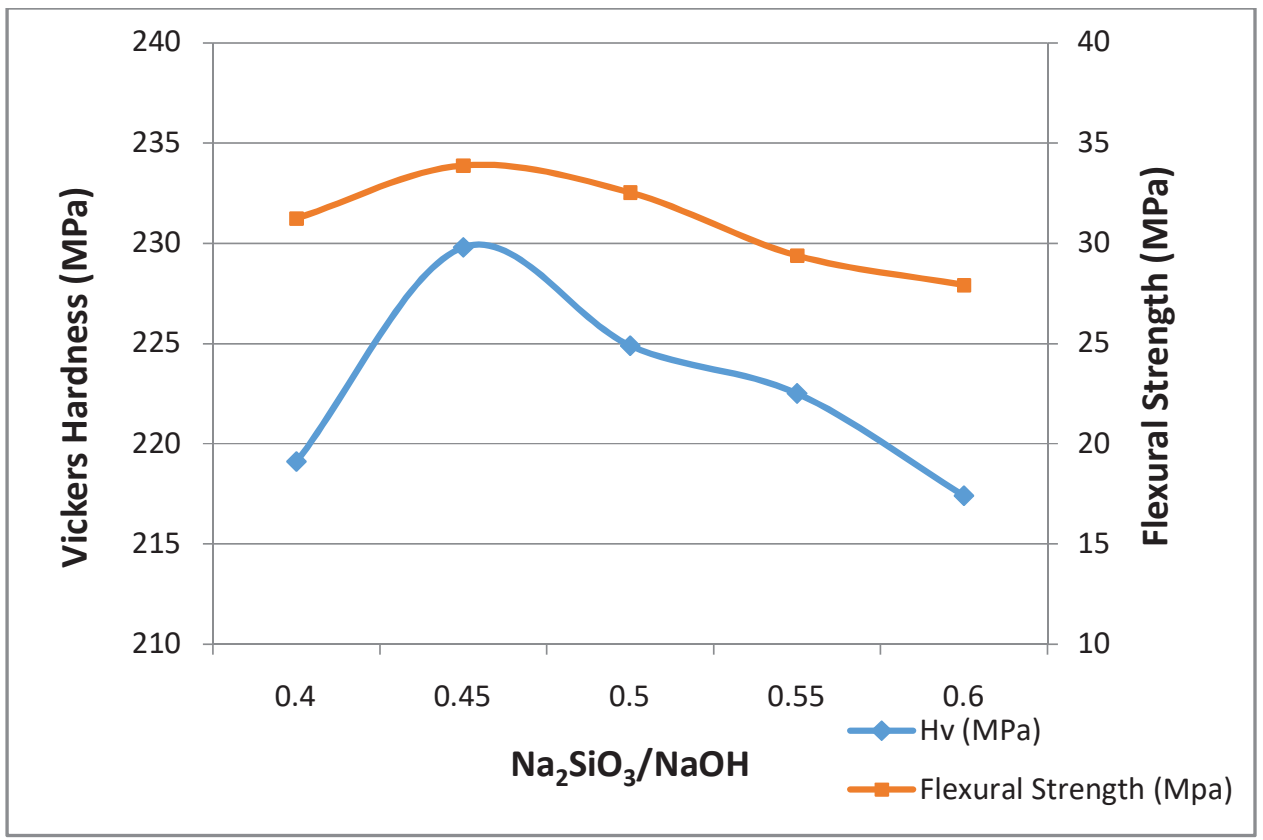

FIGURE 4 (a). Vickers hardness strength versus flexural strength for selected ratio of $\mathrm{Na}_{2} \mathrm{SiO}_{3} / \mathrm{NaOH}$ in kaolin geopolymer coating

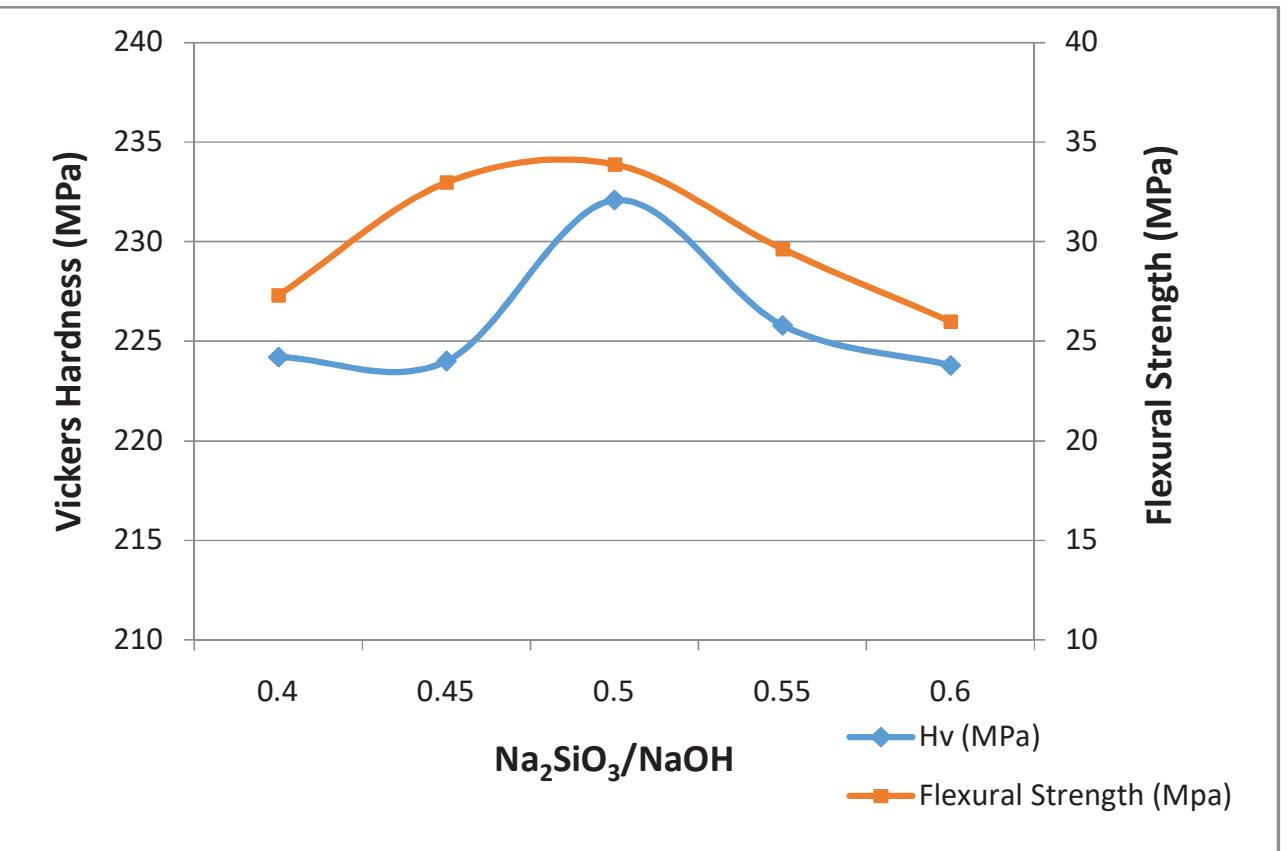

FIGURE 4 (b). Vickers hardness strength versus flexural strength for selected ratio of $\mathrm{Na}_{2} \mathrm{SiO}_{3} / \mathrm{NaOH}$ in white clay geopolymer coating

The relationship between hardness result with flexural strength (Figure 4 (a) and (b)) exhibit similar features which has maximum result at $\mathrm{Na}_{2} \mathrm{SiO}_{3} / \mathrm{NaOH}$ ratio of 0.45 and 0.50 for kaolin and white clay correspondingly. These results may lead to the successful optimization of the mix design of kaolin and white clay geopolymer coating thus obtain good performance in term of mechanical strength [24]. 


\section{Summary}

In conclusion, an optimum mix design of kaolin and white clay geopolymer coating is further verified by all the findings which leads to an optimum silicate/ $\mathrm{NaOH}$ ratio of 0.45 and 0.50 for kaolin and white clay while other parameters are kept constant such as solid/liquid ratio $=1.0$ and $\mathrm{NaOH}$ molarity $=8 \mathrm{M}$.

\section{Acknowledgements}

The authors gratefully acknowledge Center of Excellence Geopolymer and Green Technology (CEGeoGTech) and School of Materials Engineering, UniMAP for their expertise and support. The authors would also like to thank for the funding support from the "Partnership for Research in Geopolymer Concrete" (PRIGeoC-689857) sponsored by the European Union.

\section{REFERENCES}

1. Davidovits, Joseph., Journal of Thermal Analysis and calorimetry 37.8, 1633-1656 (1991)

2. Comrie, D. C., Paterson, J. H., \& Ritcey, D. J. "Geopolymer technologies in toxic waste management" (Proceedings of Geopolymer, 1988), pp. 107-123

3. Mustafa Al Bakri, A.M., Kamarudin, H., Bnhussain, M., Nizar, K., Rafiza, A.R., Zarina, Y, Advanced Materials Science 30.1, 90-97 (2012)

4. Mustafa A1 Bakri, A.M., Kamarudin, H., Bnhussain, M., Rafiza, A.R., Zarina, Y, ACI Materials Journal 109.5, 503-508 (2012)

5. Liew, Y.M., Kamarudin, H., Mustafa Al Bakri, A.M., Binhussain, M., Luqman, M., Khairul Nizar, I., Ruzaidi, C.M., Heah, C.Y, Physics Procedia 22, 312-317 (2011)

6. Temuujin J., Minjigmaa A., Rickard W., Lee M., Williams I., Van Riessen A, Applied Clay Science, 265-270 (2009)

7. Temuujin, J., Minjigmaa, A., Rickard, W., \& Van Riessen, A., Journal of thermal analysis and calorimetry 107.1, 287-292 (2012)

8. Mohd Mustafa Al Bakri A.M., Kamarudin H., Bnhussain M., Khairul Nizar I., Mastura W. I. W., Journal of Asian Scientific Research, 247-253 (2011)

9. Salwa, M. S., Al Bakri, A. M., Kamarudin, H., Ruzaidi, C. M., Binhussain, M., \& Zaliha, S. S., Australian Journal of Basic and Applied Sciences 7.5, 246-257 (2013)

10.Davidovits J. "Chemistry and Geopolymeric Systems Terminology” Proceedings Geopolymer, 1999)

11.Liew, Y.M., Kamarudin, H., Mustafa Al Bakri, A.M., Luqman, M., Khairul Nizar, I., Heah, C.Y, Australian Journal of Basic and Applied Sciences 5.9, 441-449 (2011)

12.Roy, D. M., Cement and Concrete Research 29.2, 249-254 (1999)

13.Mendelovici, E, Journal of Thermal Analysis and Calorimetry 49.3, 1385-1397 (1997)

14.Heah, C.Y., Kamarudin, H., Mustafa Al Bakri, A.M., Luqman, M., Khairul Nizar, I., Liew, Y.M, Australian Journal of Basic and Applied Sciences 5.7, 1026-1035 (2011)

15.Cioffi, R., Maffucci, L., Santoro, L., Resources, Conservation and Recycling 40.1, 27-38 (2003)

16.Zarina, Y., Mustafa Al Bakri, A.M., Kamarudin, H., Nizar, I.K., Rafiza, A.R, Advanced Materials Science $34.1,37-43(2013)$

17.Davidovits J. "Geopolymer Chemistry and Applications 2nd edition” (Geopolymer Chemistry and Application, 2008)

18.Zhang, Z., Yao, X., Zhu, H., Applied clay science 49.1, 7-12 (2010)

19.Igarashi, S., Bentur, A., \& Mindess, S., Advanced Cement Based Materials 4.2, $48-57$ (1996)

20.Choi, H., Toutanji, H. A., Gilbert, J. A., \& Alldredge, D. J., Journal of Materials in Civil Engineering 25.12, 1984-1989 (2012)

21.Malhotra, V. M., Concrete international 21.5, 61-66 (1999)

22.Kosmatka S. H., Collins T. C. "Finishing Concrete Slabs with Color and Texture" (Portland Cement Association, 2004), pp. 1-63

23.Yahya, Z., Abdullah, M.M.A.B., Hussin, K., Ismail, K.N., Sandu, A.V., Vizureanu, P., Razak, R.A, Revista de Chimie 64.12, 1408-1412 (2013)

24.Kong, D. L., Sanjayan, J. G., \& Sagoe-Crentsil, K., Cement and Concrete Research 37.12, 1583-1589 (2007) 